\title{
Isolasi Senyawa Polifenol Black Garlic dan Uji Toksisitasnya Terhadap Larva Udang (Artemia salina Leach)
}

\author{
(Isolation of Polifenol Black Garlic and Toxicity Assay \\ toward Artemia salina Leach) \\ SANTI NUR HANDAYANI ${ }^{1 *}$, LIDYA CAHYO BAWONO ${ }^{1}$, DIANA PRAMESTI \\ AYU ${ }^{1}$, HESTI NURRIZQI PRATIWI ${ }^{1}$ \\ ${ }^{1}$ Jenderal Soedirman University, Chemistry Departement, Faculty of Mathematic and Natural \\ Science
}

Diterima 7 Mei 2018, Disetujui 10 September 2018

\begin{abstract}
Abstrak: Kanker adalah salah satu penyakit yang disebabkan oleh pembelahan sel yang tidak terkendali. Kanker serviks merupakan kanker yang diderita oleh banyak wanita. Pengobatan alternatif penyakit kanker adalah menggunakan bawang putih hitam. Bawang putih hitam adalah hasil dari pengolahan bawang putih dengan suhu dan kelembaban tinggi tanpa penambahan zat lain. Dalam proses itu terjadi reaksi Maillard yang menyebabkan perubahan warna, bau, dan rasa asli pada bawang putih. Reaksi seperti itu juga menyebabkan peningkatan beberapa senyawa bioaktif seperti $S$-allyl cysteine (SAC), asam amino, flavonoid, dan polifenol. Guna menentukan sifat racun dari ekstrak bawang putih hitam, perlu dilakukan isolasi senyawa polifenol dan uji toksisitas terhadap Artemia salina leach. Penentuan nilai $\mathrm{LC}_{50}$ dengan aplikasi SPSS yang diperoleh dari ekstrak bawang putih hitam pada variasi waktu proses penuaan 30 hari dan 40 hari menunjukkan konsentrasi 682,433 dan 572,403 ppm.
\end{abstract}

Kata kunci: Reaksi Maillard, polifenol, bawang putih hitam, dan BSLT.

\begin{abstract}
Cancer is one of diseases caused by cell division that is uncontrollable. Cervical cancer is a cancer that suffered by many women. Alternative medicine of cancer disease is use black garlic. Black garlic is the result of processing the garlic with high temperature and humidity without addition of other substances. In that process occur Maillard reaction that cause changes in the color, smell, and taste of the original on the garlic. Such reaction also lead to an increase some bioactive compounds such as S-allyl cysteine (SAC), amino acids, flavonoids, and polyphenols. To determine the toxic properties of black garlic extract, it is necessary to do isolation of polyphenolic compounds and toxicity test against Artemia salina leach. When calculated by SPSS application, the obtained $\mathrm{LC}_{50}$ values of black garlic extract on the aging prosess time variations of 30 days and 40 days showed concentration of 682.433 and $572.403 \mathrm{ppm}$.
\end{abstract}

Keywords: Maillard reaction, polifenol black garlic dan BSLT.

\footnotetext{
* Penulis korespondensi, HP 08164244957

e-mail: santinurhandayani@yahoo.com
} 


\section{PENDAHULUAN}

KANKER merupakan salah satu penyakit yang disebabkan oleh pembelahan sel yang tidak terkontrol dan tidak terkendali. Hal itu mampu menyebabkan kerusakan pada suatu jaringan tersebut dan jaringan di sekitarnya. Salah satu penyakit kanker yang masih banyak memakan banyak korban terutama pada kaum wanita adalah kanker serviks. Menurut Tim Cancer Help (2010), setiap hari di Indonesia diperkirakan terdapat 40-45 kasus baru dan sekitar 20-25 wanita meninggal dikarenakan kanker serviks. Beberapa upaya tim medis untuk menumpas penyakit tersebut saat ini seperti kemoterapi, penyinaran, dan operasi pembedahan masih banyak membawa dampak negatif bagi tubuh manusia. Oleh karena itu perlu adanya pengobatan alternatif untuk menghambat pertumbuhan sel kanker dengan meminimalkan efek samping yang terjadi. Salah satu bahan yang dapat digunakan adalah black garlic.

Black garlic merupakan hasil pengolahan terhadap bawang putih dengan suhu dan kelembapan yang tinggi tanpa penambahan zat lain dan prosesnya dinamakan proses aging. Suhu yang ideal untuk membuat black garlic adalah $70{ }^{\circ} \mathrm{C}^{(1,2)}$. Pada proses aging tersebut terjadi suatu reaksi yang bernama reaksi Maillard. Reaksi Maillard dapat menyebabkan perubahan warna, bau, serta rasa asli pada bawang putih. Perubahan karakteristik yang terjadi pada proses tersebut adalah perubahan warna bawang putih menjadi hitam, rasa bawang menjadi manis serta bau menyengat pada bawang sudah tidak lagi tercium. Selain perubahan warna, reaksi tersebut juga menyebabkan peningkatan beberapa senyawa bioaktif seperti S-allyl cysteine (SAC), amino asam, flavonoid, polifenol, dll. Apabila dibandingkan dengan bawang putih segar, black garlic menunjukkan antioksidan kuat dan kemampuan menangkap aktivitas radikal bebas $^{(3)}$. Salah satu kandungan dalam black garlic yang akan diujikan adalah senyawa metabolit sekunder polifenol.

Berdasarkan penelitian yang telah dilakukan oleh Il Sook Choi et al ${ }^{(4)}$ menyatakan bahwa black garlic memiliki aktivitas antiradikal yang kuat dalam uji penangkapan aktivitas radikal bebas terhadap hewan dan manusia. Kekuatan antiradikal pada black garlic lebih kuat dibandingkan pada bawang putih segar. Salah satu senyawa metabolit sekunder yang berperan sebagai antioksidan adalah polifenol. Proses aging menyebabkan peningkatan senyawa polifenol yang terkandung didalam black garlic. Proses aging pada bawang putih memicu peningkatan fraksi bebas asam fenolik, sedangkan menurunkan fraksi ester, glikosida yang menyebabkan peningkatan bentuk fenol bebas. Proses aging ini menyebabkan perubahan senyawa bioaktif pada bawang putih seperti polifenol yang dapat digunakan sebagai antikanker(5).

Berdasarkan penjelasan tersebut maka perlu dilakukan isolasi senyawa polifenol serta uji toksisitas terhadap Artemia salina Leach.

\section{BAHAN DAN METODE PENELITIAN}

BAHAN. Bawang putih lanang, etanol, larva udang Artemia salina Leach, air laut, ragi, tween 60, dan asam galat.

ALAT. Mortar, tabung reaksi, rice cooker, Erlenmeyer, alat-alat gelas, rotary evaporator, mikropipet, lampu, dan spektrofotometer UV-Vis.

METODE. Proses Aging Black Garlic ${ }^{(6)}$. Bawang putih yang digunakan adalah jenis lanang. Bawang tersebut dilakukan proses aging dengan temperatur $70{ }^{\circ} \mathrm{C}$ dan kelembapan $75 \%$ dengan variasi waktu 30 dan 40 hari. Selama proses aging tidak dilakukan penambahan bahan apapun. Bawang putih akan berubah warna dari putih menjadi abuabu kemudian hitam setelah satu bulan kemudian. Black garlic yang dihasilkan lunak tidak berbau khas bawang yang menyengat dan rasanya manis dengan sedikit asam.

Ekstrak Black Garlic. Black garlic sebanyak $100 \mathrm{~g}$ dihaluskan dengan menggunakan mortar untuk diekstraksi, larutan yang telah diekstraksi kemudian disentrifugasi pada $3000 \mathrm{rpm}$ selama 20 menit untuk mengisolasi senyawa metabolit sekunder polifenol untuk uji toksisitas terhadap larva udang (Artemia salina Leach).

Penentuan Kadar Polifenol Total dengan Spektrofotometer UV-Vis. Tahap pertama adalah membuat larutan standar asam galat yang kemudian diujikan dengan spektrofotometer UV-Vis untuk diperoleh persamaan regresi. Persamaan regresi tersebut akan digunakan untuk menentukan kadar senyawa polifenol total dalam black garlic. Tahap kedua adalah melarutkan 10 mg ekstrak black garlic ke dalam $10 \mathrm{~mL}$ etanol untuk digunakan sebagai larutan induk dengan konsentrasi 1000 ppm. Larutan induk tersebut kemudian dibuat variasi konsentrasi 500 ppm, 300 ppm, 250 ppm, dan 100 ppm untuk diujikan dengan menggunakan spektrofotometer UV-Vis.

UjiToksisitas Metode Brine Shrimp Lethality Test (BSLT). Tahap pertama adalah pembiakkan larva udang $A$. salina. Air laut dimasukkan ke dalam suatu tempat kecil yang sudah dibagi menjadi dua kamar menggunakan sekat jaring. Telur udang $A$. salina dimasukkan secukupnya ke dalam salah satu ruang 
yang atasnya di tutup dengan papan agar ruangan tersebut gelap. Bagian wadah yang lain dibiarkan terbuka dan diberi lampu untuk menarik udang yang menetas melalui lubang sekat, sehingga larva dapat dipisahkan dari bagian telur dan udang yang tidak sehat.

Telur udang $A$. salina akan menetas menjadi udang kecil setelah dua hari ( $2 \times 24$ jam $)$ dan siap untuk dilakukan uji. Sebanyak $50 \mathrm{mg}$ ekstrak black garlic diambil dan dilarutkan dengan $25 \mathrm{~mL}$ air laut. Ekstrak ditambahkan dengan tween 80 pada konsentrasi 250 ppm untuk membantu melarutkan dengan sempurna dalam air laut. Beberapa larutan utama ekstrak black garlic diambil menggunakan mikropipet dan diencerkan menjadi beberapa variasi konsentrasi. Setiap tabung diisi dengan sepuluh larva udang dan air laut, diberikan dua tetes ragi $(3 \mathrm{mg} / \mathrm{mL}$ air laut) sebagai nutrisi mereka. Tabung diberikan sampel uji dalam jumlah tertentu dan diencerkan dengan air laut hingga $5 \mathrm{~mL}$, hingga diperoleh konsentrasi akhir masing-masing yaitu $1000 ; 750 ; 500 ; 250 ; 125$; dan $62,5 \mathrm{ppm}$. Tabung kontrol adalah konten yang sama dengan tabung uji tetapi tanpa sampel. Tabung reaksi dan tabung kontrol diinkubasi secara terbuka dan diberi cahaya selama 24 jam. Jumlah larva hidup untuk masing-masing konsentrasi dihitung dan dicatat untuk menentukan persentase kematian udang serta $\mathrm{LC}_{50}$. Jika ada larva mati dalam larutan kontrol, jumlah larva yang mati dalam larutan kontrol dikurangi dengan jumlah larva yang terbunuh dalam larutan uji. Berdasarkan, persentase kematian dihitung sebagai berikut:

$\%$ Kematian larva udang $=(\Sigma$ larva hidup kontrol- $\Sigma$ larva hidup perlakuan $) /(\Sigma$ larva hidup kontrol $) \times 100 \%$

\section{HASIL DAN PEMBAHASAN}

Hasil Proses Aging. Berdasarkan data di bawah perubahan bawang putih selama proses aging. Perubahan warna bawang putih menjadi hitam dikarenakan adanya reaksi Maillard dimana kandungan gula dan asam amino membentuk senyawa melanoidin (substansi yang mengubah bawang putih menjadi hitam $)^{(3,7)}$. Selain itu, proses aging tersebut dapat mengurangi rasa dan bau yang menyengat menjadi rasa manis dan sedikit asam, hal ini dikarenakan terjadinya penurunan $\mathrm{pH}$ dari 6 menjadi $3,8^{(7,8)}$.

Analisis Kadar Polifenol. Pada penetapan kadar polifenol total dilakukan dengan menggunakan reagen Folin-Ciocalteu 10\% untuk membentuk larutan berwarna yang dapat diukur absorbansinya. Pereaksi Folin-Ciocalteu akan menginduksi fenolat (garam alkali) atau gugus fenolik-hidroksi mereduksi asam heteropoli (Fosfomolibdat-fosfotungstat) yang terdapat di dalam pereaksi Folin-Ciocalteu menjadi suatu kompleks molibdenum-tungsten. Senyawa fenolik hanya dapat bereaksi dengan reagen FolinCiocalteu pada saat suasana basa agar terjadi disosiasi proton pada senyawa fenolik menjadi ion fenolat, maka dilakukan penambahan $\mathrm{Na}_{2} \mathrm{CO}_{3} 7,5 \%$. Gugus hidroksil pada senyawa fenolik akan bereaksi dengan reagen Folin-Ciocalteu membentuk kompleks molibdenum-tungsten berwarna biru yang dapat dideteksi dengan spektofotometer UV-Vis ${ }^{(9)}$.

Pada penentuan kadar polifenol total digunakan asam galat sebagai larutan standar acuan, dan hasilnya dinyatakan sebagai persen ekivalen asam galat (EAG) yang kemudian dibuat kurva baku asam galat dengan melarutkan asam galat dengan variasi konsentrasi 8 ppm, 10 ppm, 12 ppm, 14 ppm, dan 18 ppm. Dari kurva baku tersebut diperoleh persamaan regresi linier yang kemudian digunakan untuk menentukan

Tabel 1. Hasil perubahan bawang putih setelah proses aging.

\begin{tabular}{|c|c|c|c|c|c|}
\hline Gambar & $\begin{array}{c}\text { Lama } \\
\text { proses } \\
\text { aging } \\
\text { (hari) }\end{array}$ & Rasa & Warna & Tekstur & Bau \\
\hline & 0 & $\begin{array}{c}\text { Khas } \\
\text { bawang } \\
\text { putih }\end{array}$ & $\begin{array}{c}\text { Putih } \\
\text { kekuning- } \\
\text { kuningan }\end{array}$ & $\begin{array}{c}\text { Keras, } \\
\text { dan } \\
\text { lengket }\end{array}$ & $\begin{array}{c}\text { Bau khas bawang } \\
\text { putih }\end{array}$ \\
\hline & 30 & $\begin{array}{c}\text { Manis, } \\
\text { asam } \\
\text { sedikit } \\
\text { pahit }\end{array}$ & Hitam & $\begin{array}{c}\text { Kenyal, } \\
\text { dan } \\
\text { kering }\end{array}$ & $\begin{array}{l}\text { Bau bawang sudah } \\
\text { tidak tercium }\end{array}$ \\
\hline & 40 & $\begin{array}{c}\text { Manis, } \\
\text { asam } \\
\text { sedikit } \\
\text { pahit }\end{array}$ & Hitam & $\begin{array}{c}\text { Keras } \\
\text { dan } \\
\text { kering }\end{array}$ & $\begin{array}{l}\text { Bau bawang sudah } \\
\text { tidak tercium }\end{array}$ \\
\hline
\end{tabular}


kadar polifenol dalam black garlic. Pada penelitian persamaan regresi linier yang diperoleh adalah $\mathrm{y}=$ $0,0427 \mathrm{x}-0,0022$ dan nilai $\mathrm{R}^{2}=0,982$.

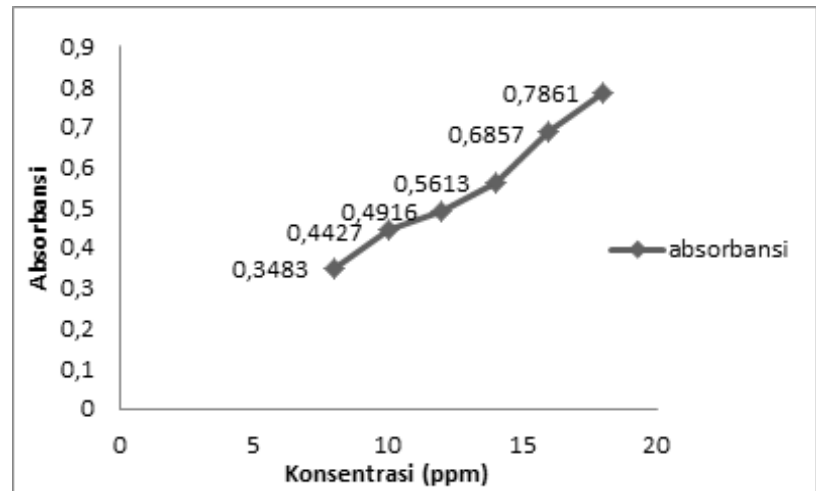

Grafik 1. Persamaan regresi asam galat.

Dari data tersebut dapat diperoleh kadar polifenol total dalam black garlic sebagai berikut :

Tabel 2. Kadar senyawa polifenol total dalam black garlic.

\begin{tabular}{cc}
\hline Lama Proses Aging (hari) & Kadar Polifenol Total (ppm) \\
\hline 0 & 3,5 \\
30 & 39,79 \\
40 & 57,38
\end{tabular}

disajikan pada Tabel 3. Tabel tersebut menunjukkan bahwa semakin tinggi konsentrasi ekstrak black garlic yang diuji, maka persentase kematian larva $A$. salina Leach semakin tinggi, sedangkan dalam kontrol tidak terdapat ekstrak black garlic tidak ditemukan larva yang mati. Hal ini dikarenakan dalam tabung kontrol tidak terdapat ekstrak sampel yang bersifat toksik. Menurut Carballo ${ }^{(11)}$, kematian larva A. salina Leach disebabkan oleh komponen-komponen bioaktif dari ekstrak sampel, bukan disebabkan kelaparan sehingga dilakukan pembandingan antara perlakuan dan kontrol.

Dengan menggunakan perhitungan aplikasi SPSS, diperoleh nilai $\mathrm{LC}_{50}$ ekstrak black garlic pada variasi lama waktu fermentasi 30 hari dan 40 hari berturutturut menunjukkan konsentrasi 682,433 dan 572,403 ppm. Hal tersebut menunjukkan bahwa ekstrak black garlic bersifat toksik terhadap larva A. salina Leach.

\section{SIMPULAN}

Selama proses aging terjadi reaksi Maillard yang menyebabkan perubahan warna bawang putih. Selain itu, reaksi Maillard juga menyebabkan berkurangnya bau khas bawang putih yang menyengat serta rasanya

Tabel 3. Data primer BSLT

\begin{tabular}{ccccccc}
\hline No & $\begin{array}{c}\text { Lama } \\
\text { Aging (hari) }\end{array}$ & $\begin{array}{c}\text { Konsentrasi } \\
\text { ekstrak (ppm) }\end{array}$ & $\begin{array}{c}\text { Larva } \\
\text { hidup rata- } \\
\text { rata }\end{array}$ & \% kematian & $\begin{array}{l}\text { Log } \\
\text { Konsentrasi }\end{array}$ & $\begin{array}{l}\text { Nilai } \\
\text { Probit }\end{array}$ \\
\hline 1 & 40 & 1000 & 1 & 90 & 3,106 & 2,950 \\
2 & 40 & 750 & 3,3 & 67 & 2,827 & 2,708 \\
3 & 40 & 500 & 7,33 & 27 & 2,529 & 2,266 \\
4 & 40 & 250 & 9 & 10 & 2,409 & 2,045 \\
5 & 40 & 125 & 9,66 & 4 & 2,282 & 1,802 \\
6 & 40 & 62,5 & 10 & 0 & 0 & 0 \\
7 & 30 & 1000 & 1,67 & 83,3 & 3,053 & 2,918 \\
8 & 30 & 750 & 5 & 50 & 2,834 & 2,711 \\
9 & 30 & 500 & 8 & 20 & 2,615 & 2,331 \\
10 & 30 & 250 & 9 & 10 & 2,500 & 2,086 \\
11 & 30 & 125 & 10 & 0 & 0 & 0 \\
12 & 30 & 62,5 & 10 & 0 & 0 & 0 \\
\hline
\end{tabular}

Berdasarkan data hasil uji menunjukkan bahwa semakin lama proses aging pada black garlic maka kadar senyawa polifenol akan semakin meningkat. Black garlic dengan dengan lama proses aging 40 hari memiliki konsentrasi tertinggi yaitu sebesar 57,38 $\mathrm{mg} / 10 \mathrm{~mL}$. Hal itu sesuai dengan pernyataan Sato et al. (10) yaitu proses fermentasi meningkatkan kandungan polifenol lebih baik dibandingkan bawang segar.

Uji Toksisitas Metode Brine Shrimp Lethality Test (BSLT). Berdasarkan uji BSLT yang dilakukan terhadap sample ekstrak black garlic, diperoleh data menjadi manis sedikit asam. Lamanya proses aging mempengaruhi kadar senyawa polifenol total. Semakin lama proses fermentasi maka akan semakin tinggi pula kadar senyawa polifenol total yang terkandung di dalam black garlic. Uji Toksisitas menunjukan bahwa semakin tinggi konsentrasi dari suatu ekstrak maka akan semakin tinggi pula persentasi kematian larva A. salina Leach. Hal ini dikarenakan kandungan komponen bioaktif di dalamnya. 


\section{UCAPAN TERIMAKASIH}

Kami ucapkan terimakasih kepada Kementrian Riset, Teknologi, dan Pendidikan Tinggi Republik Indonesia yang telah memberi kami fasilitas berupa dana hibah PKM-PE sehingga kami dapat melaksanakan penelitian ini dengan baik.

\section{DAFTAR PUSTAKA}

1. Choi, S., H.S. Cha and Y.S. Lee. Physicochemical and antioxidant properties of black garlic. Molecules. 2014. 19: 16811-23.

2. Kimura, S, Y.C. Tung, M.H. Pan, N.W Su,Y.J. Lai, K.C. Cheng. Black garlic: a critical review of its production, bioactivity, and application. Journal of Food and Drug Analysis. 2017. 25(1) : 62-70.

3. Kim JH, Nam SH, Rico CW, Kang MY. A comparative study on the antioxidative and anti-allergic activities of fresh and aged black garlic extracts. Int J Food Sci Tech. 2012. 47(6):1176-82.

4. Choi, Duk Ju., et al. Physicochemical characteristics of black garlic (Allinum sativum). J Korean Soc.Food Nutr. 2008. 37(4) : 465-71.

5. X u, G., Ye X., Chen J., Liu D. Effect of heat treatment on the phenolic compounds and antioxidant capacity of citrus peel extract. J. Agric. Food Chem. 2007. 55(2): 300-5.

6. Danan W, Yonghui F, Jun L, Jianzhong Y, Meiru W, Jin-ichi S, Changlong L. Black garlic (Allinum sativum). J Medicinal and Aromantic Plant Science and Biotechnology. 2010. 4(1):37-40.

7. Villalón, A.L. G., S. Amor, L. Monge, N. Fernández, M. Prodanov, M. Muñoz, A.M. Inarejos-García, M. Granado. In vitro studies of an aged black garlic extract enriched in S-allylcysteine and polyphenols with cardioprotective effects. Journal of functional foods. 2016. 27: 189-200

8. Lu, X., N. Li., X. Qiao., Z. Qiu, and P. Liu. Composition analysis and antioxidant properties of black garlic extract. Journal of food and drug analysis. 2016. 1-10

9. Hari S, Riza Alfian. Determination of total phenolic content of methanolic extracts red rosell (Hibiscus sabdariffa Linn) calyxs in variation of growing area by spectofotometery. J. Ilmiah Kefarmasian. 2012. 2(1) : 73-80.

10. Sato, Y. . "Does black garlic a day keep the doctor away." 2014. Accessed April 23, 2014. www. Discoverjapannow.wordpress.com/ does-black-garlica-day.

11. Carballo, J.L., Zaira L. H., Pilar P., Maria D.G. A comparison between two brine shrimp assays to detect in vitro cytotoxicity in marine natural product. BMC Biotecnol 10. 2002. 1186/1472-6750; 2:17. 